\title{
Abbreviations for Primary and Secondary Source Texts
}

Ahrī/TSU

Astarābādī/Bazm

Babinger/GdO

Brockelmann/GAL

BSOAS

CAJ

Dawlatshāh/Tažkira

Faṣịḥ Khvāfĩ/Mujmal

Ghiyāth/Ta'rīkh

Ḥāfiz Abrū/ZJT

Ḥāfiz Abrū/Zubda
Abū Bakr al-Quṭī al-Ahrī, Ta'rīkh-i

Shaikh Uwais (A History of Shaikh Uwais):

An Important Source for the History of

$\bar{A}$ dharbaijān in the Fourteenth Century, trans.

J. B. Van Loon (The Hague: Mouton \& Co., 1954).

'Azīz b. Ārdashīr Astarābādī, Bazm u Razm, intro. Köprülüzāde Meḥmed Fu'ād Bey

[Mehmed Fuad Köprülü] (Istanbul: Evkāāf Maṭa'as1, 1928).

Franz Babinger, Die Geschichtesschreiber der Osmanen und ihre Werke (Leipzig: O. Harrassowitz, 1927).

Carl Brockelmann, Geschichte der Arabischen Literatur (Leiden: Brill, 1949).

Bulletin of the School of Oriental and African Studies

Central Asiatic Journal

Dawlatshāh Samarqandī, Tazzkirat al-

Shu'arā'-yi Dawlatshāh Samarqandī, ed.

Muḥammad 'Abbāsī (Tehran: Kitāb-furūshī-yi Bārānī, 1337 [1958]).

Faṣīh al-Dīn Aḥmad Faṣị̣ Khvāfī, Mujmal-i

Fașīhī, ed. Mahmūd Farrukh (Mashhad:

Kitābfurūshī-yi Bāstān, 1339 [1961]).

'Abd Allāh b. Fath Allāh Ghiyāth, al-Ta'rīkh al-Ghiyāthī, ed. Tāariq Nāii' al-Hamdānī (Baghdad: Matba'at As'ad, 1975). Ḥāfiz Abrū, Zayl-i Jāmi ‘ al-Tavārīkh, ed. Khānbābā Bayānī (Tehran: 'Ilmī, 1317 [1939]). Ḥāfiz Abrū, Zubdat al-Tavārīkh, ed. Sayyid 
HJAS

Ibn 'Arabshāh/'Ajā'ib

Ibn Bībī/Erzi

Ibn Bībī/Houtsma

Ibn Hajar/Durar

Ibn Hajar/Inb $\bar{a}$,

JESHO

JNES

JRAS

Khvāndamīr/Humā’̄̄

Khvāndamīr/Thackston

Ibn Taghrī Birdī/Nujūm
Kamāl Ḥājj-i Sayyid Javādī (Tehran: Vizārat-i Farhang va Irshād-i Islāmī, 1380 [2001]).

Harvard Journal of Asiatic Studies

Muḥammad ibn Aḥmad b. 'Arabshāh, 'Ajā'ib al-Maqdūr fì Nawā'ib Tìmūr, ed. 'Alī Muhammad 'Umar (Cairo: Maktabat al-Anjilū al-Mișriyya, 1399 [1979]).

Ibn Bībī, El-Evāmirü'l- 'Alā'iyye fì'l-Umūri'l'Alā'iyye, ed. Adnan Sadık Erzi (Ankara: Türk Tarih Kurumu Basımevi, 1956).

Ibn Bībī, Histoire des Seldjoucides d'Asie

Mineure d'après l'Abrégé du Seldjouknāmeh d'Ibn-Bībì , ed. M. Th. Houtsma (Leiden: Brill, 1902).

Aḥmad ibn 'Alī b. Hajar al- 'Asqalānī, Durar al-Kāmina fì A 'yān al-Mi'a al-Thāmina, ed. 'Abd al-Wārith Muhammad 'Alī (Beirut: Dār al-Kutub al-'Ilmiyya, 1977).

Ahmmad ibn 'Alī b. Hajar al- 'Asqalānī, Inbā' al-Ghumr bi-Abnā' al-'Umr (Hyderabad:

Matba'at Majlis Dā'irat al-Ma'ārif al'Uthmāniyya, 1967).

Ibn Taghrī Birdī/Manhal Abū al-Mahāsin Yūsuf b. Taghrī Birdī, alManhal al-Șāfì wa al-Mustawfì ba'd al-Wāfí, ed. Muhammad Amīn (Cairo: al-Hay'a alMișriyya al-'Āmma lil-Kitāb, 1984-).

Abū al-Mahāsin Yūsuf b. Taghrī Birdī, alNujūm al-Zāhira fì Mulūk Miṣr wa-al-Qāhira, ed. William Popper (Berkeley: University of California Press, 1960).

Journal of the Economic and Social History of the Orient

Journal of Near Eastern Studies

Journal of the Royal Asiatic Society

Ghiyās al-Dīn b. Humām al-Dīn Khvāndamīr, Tārīkh-i Habīb al-Siyar fì Akhbār-i Afrād-i Bashar, ed. Jalāl al-Dīn Humā'ī (Tehran: Kitāb-khāna-yi Khayyam, 1954).

Ghiyās al-Dīn b. Humām al-Dīn Khvāndamīr, Habibu's-siyar, Tome Three, The Reign of the Mongol and the Turk, ed. and trans. Wheeler 
Kutubī/TAM

Maqrīzīl'Ashūr

Maqrīzī/Ziyāda

Mīrkhvānd/Rawża

Nakhjivānī/Dastūr

Natanzī/Aubin

Qazvīnī/Nuzhat

Qazvīnī/TG

Qazvīnī/ZTG

Rashīd al-Dīn/Jāmi ‘

Rashīd al-Dīn/Shu 'ab
Thackston (Cambridge, MA: Department of Near Eastern Languages and Civilizations, Harvard University, 1994).

Mạ̣mūd Kutubī, Tārīkh-i Āl-i Muzaffar, ed. 'Abd al-Husayn Navā'̄ '̀ (Tehran:

Kitābfurūshī-yi Ibn Sīnā, 1956).

Taqī al-Dīn Aḥmad b. 'Alī al-Maqrīzī, Kitāb al-Sulūk li-Ma'rifat Duwal al-Mulūk, ed. 'Abd al-Fattāḥ 'Ashūr (Cairo, 1972).

Taqī al-Dīn Aḥmad b. 'Alī al-Maqrīzī, Kitāb al-Sulūk li-Ma'rifat Duwal al-Mulūk, ed.

Muhammad Muștafá Ziyāda (Cairo: Lajnat alTa'lif wa-al-Tarjama wa-al-Nashr, 1934).

Muhammad b. Khvāndshāh Mīrkhvānd, Tārīkh-i Rawżat al-Safā' (Tehran: Markazī-yi Khayyam Pīrūz, 1959-60).

Muḥammad bin Hindūshāh Nakhjivānī, Dastūr al-Kātib fì Ta'yīn al-Marātib, ed. 'Abd alKarīm 'Alīūghlī 'Alīzāda (Moscow: Izd-vo 'Nauka', Glav. red. vostochnoŭ lit-ry, 1964-76). Mu 'īn al-Dīn Națanzī, Extraits du Muntakhab al-tavārīkh-i Mu 'īnī (Anonyme d'Iskandar), ed. Jean Aubin (Tehran: Librairie Khayyam, 1957).

Ḥamd Allāh Mustawfī Qazvīnī, The

Geographical Part of the Nuzhat-al-Qulüb, ed. Guy Le Strange (Leiden: Brill; London: Luzac \& Co., 1915-19).

Hamd Allāh Mustawfī Qazvīnī, Tārīkh-i

Guzīda, ed. 'Abd al-Husayn Navā'ī (Tehran:

Amīr Kabīr, 1362 [1983]).

Zayn al-Dīn b. Hamd Allāh Mustawfī Qazvīnī, Zayl-i Tārīkh-i Guzìda, ed. İraj Afshār (Tehran: Naqsh-i Jahān, 1372 [1993]. Rashīd al-Dīn Fażl Allāh Hamadānī, Jāmi ‘ al-Tavārīkh, ed. Muhammad Rawshan and Mustafá Mūsavī (Tehran: Nashr-i Alburz, 1373 [1994]).

Rashīd al-Dīn Fażl Allāh Hamadānī, Shu 'ab-i Panjgāna (Istanbul: Topkapı Sarayı Müzesi Kütüphanesi, Ahmet III ms. 2937). 
Șafadī/A ‘yān

Samarqandī/Mațla ‘

Sāvajī/Kullīyāt

Shabānkāra’’i/Majma ‘

Shāmī/Lugal

Shāmī/Tauer

Shujā‘ ‘ì/Tārīkh

Vaṣṣāf/Tārīkh

Yazdī/Zafar-nāma

TMEN
Khalīl ibn Aybak al-Ṣafadī, A 'yān al- 'Așr waA 'wān al-Naṣr (Beirut: Dār al-Fikr al-Mu 'āṣir and Damascus: Dār al-Fikr, 1998).

Kamāl al-Dīn 'Abd al-Razzāq Samarqandī, Matla'-i Sa'dayn va Majma'-i Bahrayn, ed. 'Abd al-Husayn Navā'ī (Tehran: Shāh Riżā Muqābil Dānishgāh, 1353 [1975]).

Salmān Sāvajī, Kullīyāt-i Salmān-i Sāvajū, ed. 'Abbās 'Alī Vafā'î (Tehran: Anjuman-i Āsār va Mafākhir-i Farhangī, 1382 [2004]).

Muhammad bin 'Alī bin Muhammad Shabānkāra'̄i, Majma 'al-Ansāb, ed. Mīr Hāshim Muhaddis (Tehran: Mu'assasa-yi Intishārāt-i Amīr Kabīr, 1363 [1985]). Niz̄ām al-Dīn Shāmī, Zafernâme, ed. Necati Lugal (Ankara: Türk Tarih Kurumu Basımevi, 1949).

Niẓām al-Dīn Shāmī, Histoire des conquêtes de Tamerlan intitulée Zafar-nāma, par Nižāmuddīn Šämī, avec des additions empruntées au Zubdatu-t-Tawārihh-i Bāysunġurī de Hāfiz-i Abrū, ed. Felix Tauer (Prague: Orientální ústav/Oriental Institute, 1937). Shams al-Dīn Shujā‘ī, Tārīkh al-Malik alNāṣir Muhammad ibn Qalawūn al-Sāliḥ̄ waAwlāduhu, ed. Barbara Schäfer (Wiesbaden: Franz Steiner, 1978-85).

Storey/Persian Literature Charles Ambrose Storey, Persian Literature: A Bio-Bibliographical Survey (London: Luzac \& Co., 1927-). Gerhard Doerfer, Türkische und Mongolische Elemente im Neupersischen (Wiesbaden: Franz Steiner Verlag, 1963). 'Abd Allāh b. Fażl Allāh Vașsāa al-Ḥażrat, Tārīkh-i Vașsāf [Lithograph ed. Bombay, 1269 (1853); reprint] (Tehran: Ibn-i Sīnā, 1338 [1959]).

Sharaf al-Dīn 'Alī Yazdī, Zafar-nāma, ed. Muhammad 'Abbāsī (Tehran: Amīr Kabīr, 1336 (1957-58). 